\title{
Production of briquettes from Indonesia agricultural biomass waste by using pyrolysis process and comparing the characteristics
}

\author{
Sri Wahyu Murni ${ }^{{ }^{*}}$, Tutik Muji Setyoningrum ${ }^{\mathrm{a}}$, Muhamad Maulana Azimatun Nur ${ }^{\mathrm{a}}$ \\ ${ }^{a}$ Chemical Engineering Department, UPN “Veteran” Yogyakarta, Indonesia \\ Jl. SWK Jl. Ring Road Utara No.104, Sleman 55283, Daerah Istimewa Yogyakarta, Indonesia
}

\section{Artikel histori :}

Diterima 03-05-2021

Diterima dalam revisi 06-04-2021

Diterima 10-04-2021

Online 27-04-2021

\begin{abstract}
Indonesia biomass waste is a potential feedstock as a source of renewable energy since it can be converted into charcoal briquettes. However, the production of the briquette using pyrolysis process using the agricultural waste was lacking. In this research, biobriquette was made from palm shells, corncob and soybean stem wood due to the high availability and high cellulose content. The purpose of this research was to produce charcoal briquettes from three kind of raw materials by employing pyrolysis process and compared the characteristics. The briquette was made from different type of raw materials (palm shells, corncob and soybean stem) and the concentration of binder: 3-7 \%. Pyrolysis was done at 500 ${ }^{\circ} \mathrm{C}$, and $100 \mathrm{~kg} / \mathrm{cm}^{2}$ of pressing pressure. Results showed that, the best charcoal briquette was achieved from palm shells by using 5\% binder, which resulted $4,1 \%$ moisture content, $3.4 \%$ ash content, $15 \%$ volatile matter content, $77.5 \%$ carbon content, $7075 \mathrm{cal} / \mathrm{g}$ calorific value and $1.4 \mathrm{~kg} / \mathrm{cm}^{2}$ compressive strength. It was found that the concentration of binder and raw material influenced the quality of the briquettes. In overall, the production of the briquettes by employing pyrolysis method could meet the standard.
\end{abstract}

Keywords: binder, biomass waste, briquette, charcoal, calorific value, pyrolysis.

\section{Introduction}

Recently, the demand of energy has increased rapidly. Alternative renewable and sustainable energy is needed to fulfil the gap between depleting fossil fuel and energy demand. Biomass is the third global primary energy source after coal and petroleum. It is predicted that in near 2050, the production of biomass-based wood could produce 115 EJ/year (Hämäläinen, et al., 2011). Biomass waste is an abundant raw material, which can be used as a solid fuel. As an energy resource, biomass can be utilized directly as a solid fuel or converted via pyrolysis into charcoal briquettes. Direct combustion of biomass waste has some advantages. However, it also has some disadvantages such as difficulty in controlling the burning rate of biomass, difficulty in mechanized feeding supply, low heat density, difficulty stock handling and transportation as well as large storage requirement (Zubairu et al., 2014). These problems are associated with the low bulk density of biomass waste.

Biobriquette can be produced by using waste containing organic element such as agro-industry waste by using pyrolysis process. By using pyrolysis, large molecules can be broken down into small molecules in the absence of oxygen at high temperature (Shafizadeh, 1982).
The minimum temperature of pyrolysis is $200^{\circ} \mathrm{C}$ and then maintained at $450-500^{\circ} \mathrm{C}$. The pyrolysis of the biomass produces gas, liquid, and solid/ char, which the amount of the product depends on the kind of the process (Sheth et al., 2006). The process is divided into preheating stage, water evaporation, and breaking down the cellulose at $200^{\circ} \mathrm{C}$.

A good quality of briquette must follow some criteria such as containing smooth surface and do not leave black marks on the hands. In addition, charcoal briquettes must also meet the following criteria, easy to ignite, not smoke, gas emissions from combustion are non-toxic, watertight and the results of combustion are not moldy when stored for a long time and good burning. The advantages of using biomass waste bio-briquettes include: cheaper fuel costs, stoves can be used for various types of briquettes, are more environmentally friendly, are a renewable energy source, help overcome waste problems and reduce waste management costs (Suttibak et al., 2018; Wei et al., 2020). Characteristic of raw material, that are the ash content, fixed carbon content, volatile matter content was influenced the characteristic of charcoal briquettes.

Briquetting process requires the binder that mixed with the charcoal, then was pressed to form briquettes. The binder help hold the charcoal strongly together in place,

*Corresponding Author: +62 8121573776

Email: sriwahyumurni@upnyk.ac.id 
such that the briquettes hard enough to hold in the fire. The binder material must be combustible, various material was tested for binder application such as starch, tar, asphalt, molasses, resins and clay. However, it has been widely reported that starch is the most effective binder material (Zubairu et al., 2014).

Previous study demonstrated that agricultural waste is a potential feedstock as a bio-briquette (Chungcharoen, et al., 2020). However, not all biomass waste can be converted into bio-briquette as a fuel feedstock. Biobriquette can be utilized as fuel, if the heating value is more than 5000 cal /g (Putra, et al., 2018). In this study, bio-briquette was produced using biomass waste from agricultural waste. The quality of bio-briquettes from palm shells, corn cobs and soybean stem were compared and tested for their SNI characteristics.

\section{Material and Methods}

\subsection{Material}

Palm shell was obtained from Jambi, Sumatra, while corncob and soybean were obtained from local farmers in Sleman, Yogyakarta. The materials were varied as the source of the briquettes. The material was cleaned, washed and dried in the sun until a moisture content of $10 \%$. Cassava was used as the binder.

\subsection{Pyrolysis}

Each $500 \mathrm{~g}$ of the material was placed into the pyrolysis tube (Figure 1). The tube was connected to a heating coil which used to maintain the temperature. The temperature of pyrolysis was $500^{\circ} \mathrm{C}$. After the pyrolysis was done, (which is indicated by the absence of smoke coming out), the equipment was then turned off and left overnight.

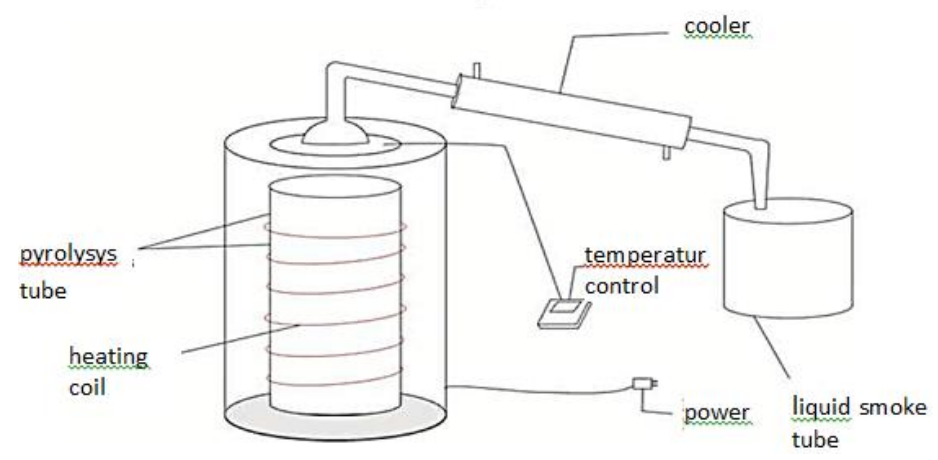

Figure 1. Pyrolysis Apparatus

\subsection{Making briquette}

\subsubsection{Crushing and sieving}

The charcoal result was then crushed with a disc mill and then sieved to obtain the specified mesh size which was specified at $-35+50$ mesh.

\subsubsection{Briquette production}

The powdered charcoal was then mixed with the binder at $3-7 \%$ and $10 \%$ water. The molding process of the briquette was performed to obtain the briquettes shape, making it easier to use, handle and store. The molding process was done by using of $100 \mathrm{~kg} / \mathrm{cm}^{2}$ pressure strength to reduce the moisture content, to enhance the drying process of the briquettes and increase the heat content.

\subsubsection{Drying}

The drying process was performed after molding process. This was done to obtain better evaporation process after solidification. The briquette was dried at $80^{\circ} \mathrm{C}$ for 2 hours.

\subsection{Charcoal Briquette Analysis}

Charcoal briquette was analyzed as according to standard published procedures. The standard includes ash content (ASTM 3174), moisture content (ASTM D-3173), bound carbon content (ASTM D 5142-02), volatile matter content (ASTM D-3175), and calorific value (ASTM 2105). The briquettes were also analyzed to determine compressive strength test using Universal Testing Machine.

\section{Result and Discussion}

Charcoal briquettes from palm shells, corncob and soybean stem were produced by pyrolysis at $500^{\circ} \mathrm{C}$, then crushed, sieved, mixed with various of binder, pressed and dried. The characteristic of briquettes then was tested. The effect of amount of binder on the characteristics of briquettes is presented in the following discussion.

\subsection{Moisture Content}

The moisture content in charcoal briquettes affected the quality of briquettes produced, including the caloric value during combustion. The material type and concentration of binder also influenced the moisture contents. The water content of charcoal briquettes based on SNI is $8 \%$ maximum. The effect of binder concentration on the moisture content of briquettes is presented in Figure 2.

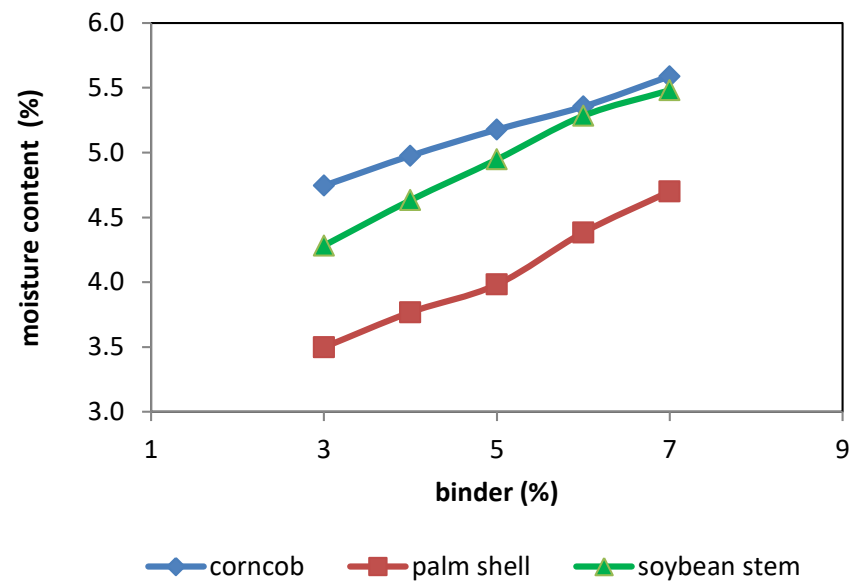

Figure 2. The effect of binder concentration to moisture content 
The result of this research showed that the highest of water content $(5.6 \%)$ in charcoal briquettes from corncob at binder concentration of $7 \%$ while the lowest water content $(3.5 \%)$ in charcoal briquettes from palm shells at binder concentration of $3 \%$. Thus, the moisture content of the briquettes in this study fulfilled the SNI 01-6235-2000 and also agree with recommendation by Chin et al (2000).

\subsection{Ash Content}

After burned down, the ash content of briquette charcoal still left. The main element of ash is silica which has less effect on the calorific value. This indicated that the higher the ash content could lower the briquette quality. Ash contained in solid fuel is a mineral that does not burned during the combustion process. The maximum ash content of briquettes based on SNI 01-6235-2000 is 8\%. The effect of binder concentration on ash content is shown in Figure 3.

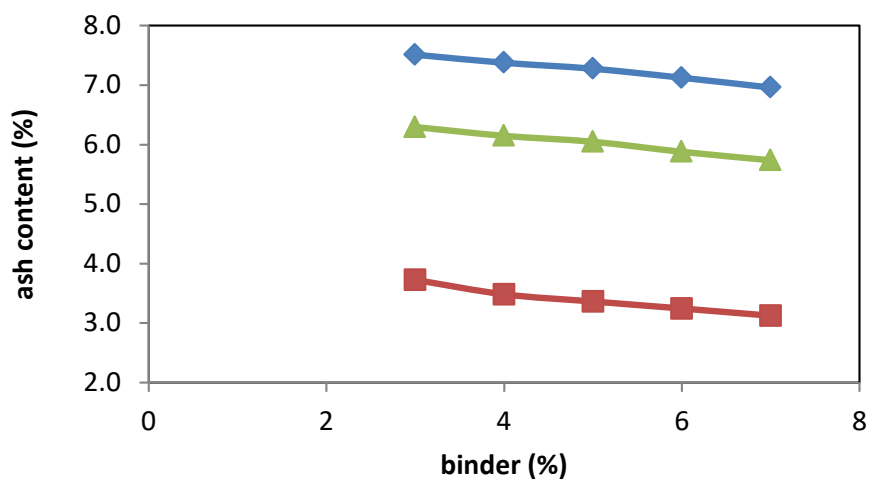

$\neg$ corncob $\rightarrow$-palm shell $\rightarrow$ soybean stem

Figure 3. Effect of binder concentrations on ash content

Based on Figure 3, the ash content is influenced by the type of the materials. Palm shell has the lowest ash content, while corncob has the highest ash content. However, when the binder concentration is increased, the ash content is slowly decreased for all materials. The result showed that the lowest ash content $(3.1 \%)$ was found from palm shells at the concentration $7 \%$ of the binder, while the highest ash content $(7.5 \%)$ was found in charcoal briquettes from corncob at the concentration of $3 \%$ binder. Previous research recommended that ash content for good briquettes is around 3-4\% (Zubairu et al., 2014). In this study, briquette from palm shell has met the standard.

\subsection{Volatile matter content}

Volatile matter content is volatile substances that can evaporate which resulted from the decomposition of substances in the charcoal. High volatile matter content in charcoal briquettes will cause more smoke when the charcoal is burned. The volatile matter content in briquette plays important role in solid fuels in terms of flammability and combustibility (Syarif et al., 2019).

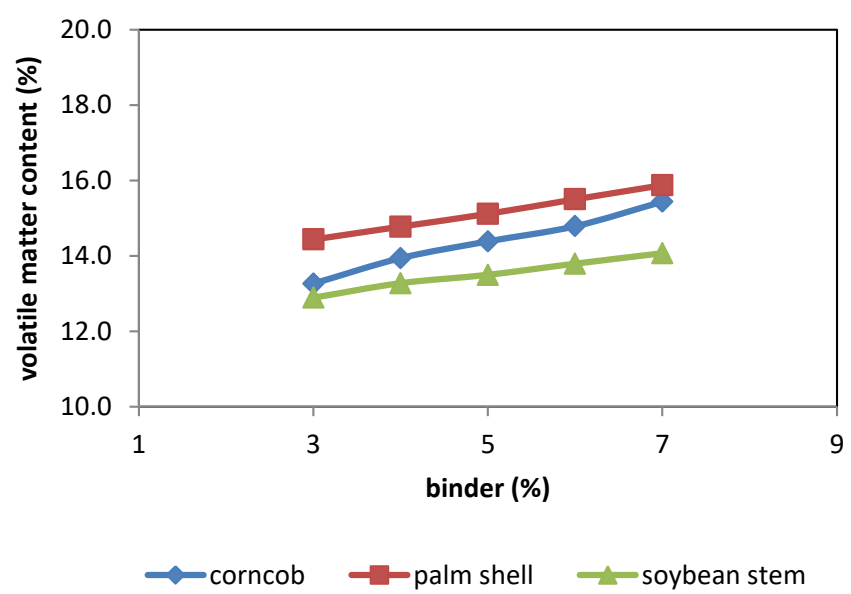

Figure 4. Effect of binder concentrations on volatile matter content

The effect of binder concentration on volatile matter content shown in Figure 4. It is showed that the volatile matter content was influenced by the type of the wastes and the binder concentrations. The result showed that the highest volatile matter content $(15.9 \%)$ was found in charcoal briquettes from palm shell at $7 \%$ binder, while the lowest volatile matter $(12.9 \%)$ in charcoal briquettes from soybean stem was found at $3 \%$ binder.

\subsection{Fixed Carbon Content}

The amount of carbon element content in the briquette can be analyzed by using the fixed carbon content. The carbon content influenced the volatile matter. The higher the fixed carbon content, the lower the volatile material.

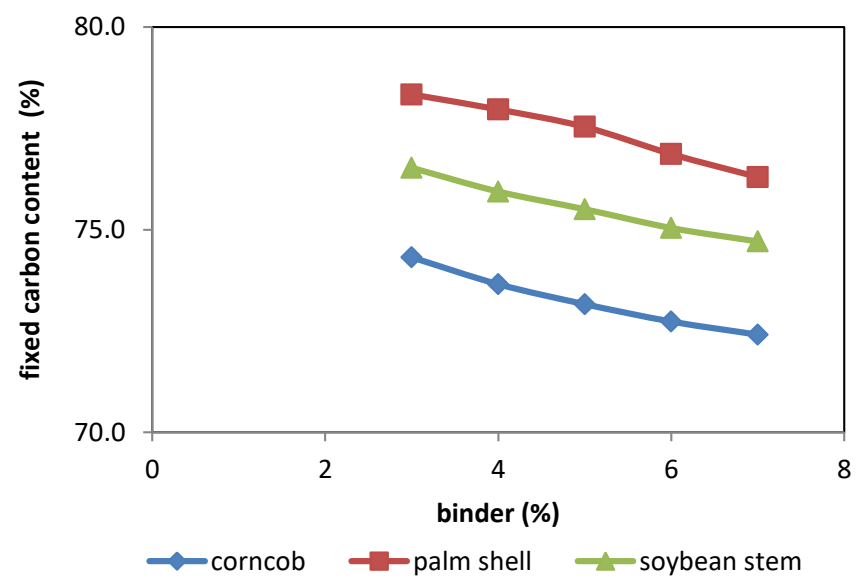

Figure 5. Effect of binder concentrations on fixed carbon content

Figure 5 shows that the concentration of binder influenced fixed carbon content. The highest fixed carbon content $(78.3 \%)$ was found in charcoal briquette from palm shell at binder concentration of $3 \%$, while the lowest fixed carbon content $(72.4 \%)$ was found in $7 \%$ binder. In overall, the increasing binder concentration resulted lower 
fixed carbon content. Different materials also influenced the fixed carbon content.

Tabel 1. Characteristics of the briquette produced in this work (1)

\begin{tabular}{lccc}
\hline Biobriquette & $\begin{array}{c}\text { Moisture } \\
\text { content }(\%)\end{array}$ & $\begin{array}{c}\text { Ash } \\
\text { content }(\%)\end{array}$ & $\begin{array}{c}\text { Volatile } \\
\text { content } \\
(\%)\end{array}$ \\
\hline Corncob & 5.4 & 7.1 & 14.7 \\
Palm shells & 4.1 & 3.4 & 15.0 \\
Soybean stem & 5.28 & 13.8 & 5.9 \\
SNI No. 1/6235/2000 & $\leq 8$ & $\leq 8$ & $\leq 15$ \\
\hline
\end{tabular}

\subsection{Calorific value/Heating value}

Calorific value or heating value is the amount of heat produced per unit mass of briquette. The calorific value determines the quality of the briquettes produced. The higher the calorific value, the higher quality of the briquettes. The calorific value needs to be analyzed to determine the value of the heat combustion produced by briquettes. The results of the the calorific value at different binder concentrations and kind of raw materials are shown in Figure 6. All of briquettes produce in this research have calorific value higher than $5500 \mathrm{Kcal} / \mathrm{Kg}$ which has met SNI standard.

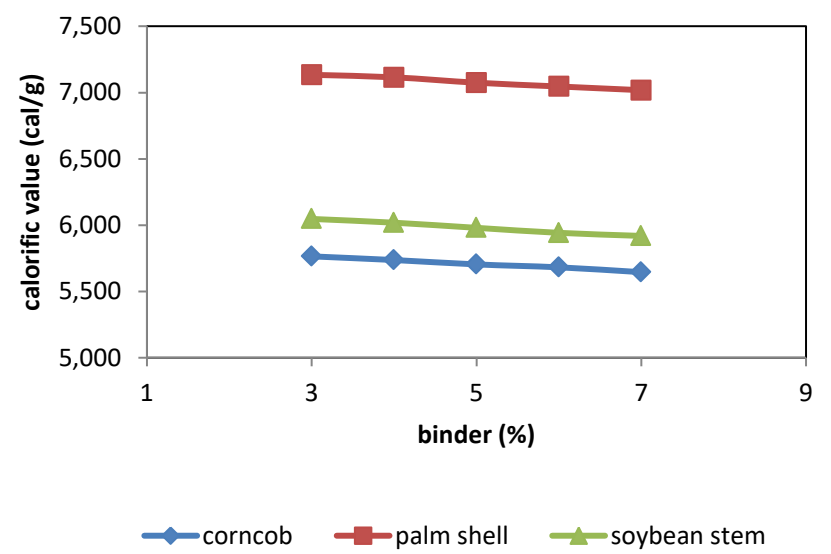

Figure 6. Effect of binder concentrations on calorific value

Generally, the calorific value decreases with the increasing of the binder/adhesive concentration. In this work, the briquette sample produced from palm shells was found to have higher calorific value than briquettes from corncob and soybean stem. Previous researcher reported that the mixture of low rank coal and palm shell resulted $6438 \mathrm{kcal} / \mathrm{kg}$ (Sipatuhar et al., 2018), which is lower compared to this finding.

\subsection{Compressive Strength}

The compressive strength test was aimed to determine the strength of the briquettes to know the strength of the briquette pressure. The profile for compressive strength as function of binder concentration is shown in Figure 7.

Figure 7 shows that the more the binder concentration, the better the resulting compressive strength test. The binder was able to bind the briquette particles and fill the empty spaces between the briquette so produce briquettes with better density. Figure 7 shows that the highest compressive strength test $\left(1.8 \mathrm{~kg} / \mathrm{m}^{2}\right)$ was found at the binder concentration of $7 \%$ in the charcoal briquette from palm shell while the lowest $\left(0.4 \mathrm{~kg} / \mathrm{m}^{2}\right)$ was found from corncob at the binder concentration of $3 \%$. Palm shell has a greater particle density so that the level of hardness is also larger than other raw materials.

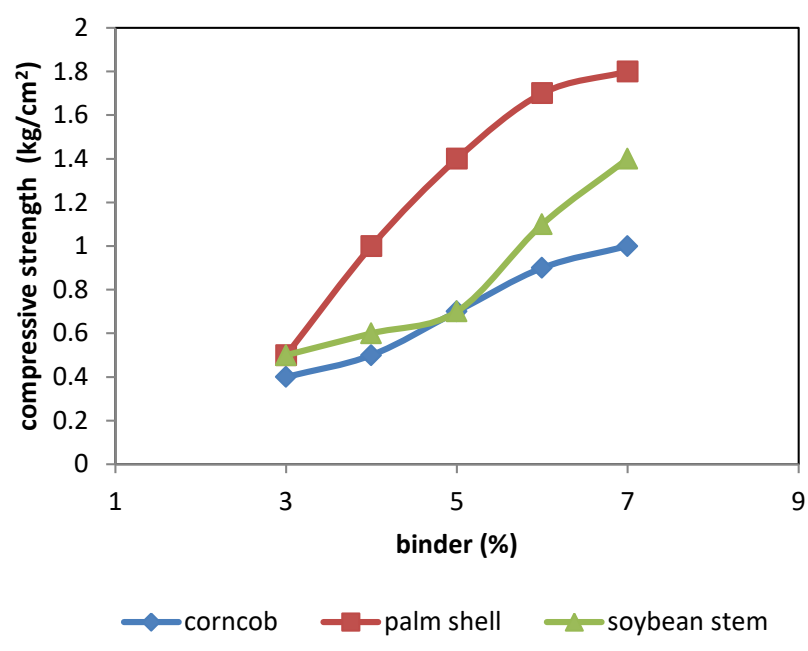

Figure 7. Effect of binder concentrations on compressive strength

\subsection{Characteristic Briquettes}

The values of the best briquettes charcoal produced in this research were presented in Table 1 and Table 2. All of the charcoal briquettes have fulfilled the parameters. However, only charcoal briquette from palm shells has met the fixed carbon content parameter.

Tabel 2. Characteristics of the briquette produced in this

\begin{tabular}{lccc} 
& work (2) & Calorific \\
Bio-briquette & $\begin{array}{c}\text { Fixed } \\
\text { carbon } \\
\text { content } \\
(\%)\end{array}$ & $\begin{array}{c}\text { Compressive } \\
(\mathrm{cal} / \mathrm{g})\end{array}$ & $\begin{array}{c}\text { strength } \\
\left(\mathrm{kg} / \mathrm{cm}^{2}\right)\end{array}$ \\
\hline Corncob & 72.7 & 5,682 & 0.9 \\
Palm shells & 77.5 & 7,075 & 1.4 \\
Soybean stem & 75.0 & 5,942 & 1.1 \\
SNI No. 1/6235/2000 & $\geq 77$ & $\geq 5,000$ & - \\
\hline
\end{tabular}

\section{Conclusion}

This research showed that different kind of raw materials and binder concentrations influenced the quality of briquette. The increasing binder concentration enhanced the calorific value and compressive strength of the briquette. All selected raw materials have met SNI briquette standard. The highest calorific value was found from palm shell.

\section{Acknowledgements}

The authors are pleased to acknowledge Lembaga Penelitian dan Pengabdian Masyarakat (LPPM) Universitas Pembangunan Nasional Veteran Yogyakarta for financial support with contract number B/105/UN.62/PT/VII/2020. 


\section{References}

Chin OC, Siddiqui KM. 2000. Characteristics of some biomass briquettes prepared under modest die pressures. Biomass Bioenergy, 18, 223-228.

Chungcharoen T, Srisang N. 2020. Preparation and characterization of fuel briquettes made from dual agricultural waste: Cashew nut shells and areca nuts. J. Cleaner production. 256. 120434

Hämäläinen S, Näyhä A, and Pesonen HL. 2011. Forest biorefineries: A business opportunity for the Finnish forest cluster. J. Clean. Prod. 19 1884-91

Putra HH, Mokodompit M, Kuntari, AP. 2013. Jurnal Teknologi. 6(2), 116-123.

Shafizadeh F. 1982. Introduction to pyrolysis of biomass. J. Anal. Appl. Pyrolysis. 3 (4), 283-305.

Sheth PN, Babu, BV. 2006. Kinetic Modelling of the Pyrolysis of Biomass, Proceedings of National Conference on Environmental Conservation. 453458

Sipatuhar R, Bizzy I, Faizal M, Maussa O. 2018. Bio coal briquettes Nigerian J. Technol. 37 (4), 1141-1146.
Suttibak S, Loengbudnark W. 2018. Production of Charcoal briquettes from biomass for community use, $8^{\text {th }}$-TMSE-International Conference of Mechanical Engineering, IOP Conf Series: Material Sciences and Engineering. 297

Syarif H, Rochim BC, Muslikhin H. 2019. Pemanfaatan Limbah Kulit Cacao menjadi Briket Arang sebagai Bahan bakar Alternatif dengan Penambahan Ampas Buah Merah, Jurnal Rekayasa Proses. 13, 1, 57-64

Wei, J., Gefu L, James A, Thongcao Z, Chunbo M. 2020. Research Progress of Energy Utilization of Agriculture Waste in China: Blibiometric Analysis by Citespace. Suatainability. 12,812.

Zubairu A, Sadiq AG. 2014. Production and Characterization of Briquette Charcoal by carbonization of Agro-Waste. Energy and power. $4(2), 41-47$. 